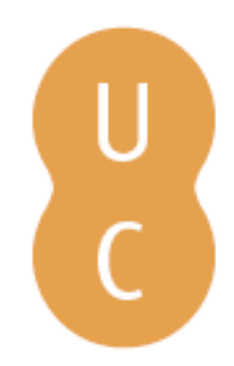

\title{
nommalina
}

\section{Effect of teaching creative and critical thinking skills on defense styles and mental health in adolescents}

Autor(es): $\quad$ Kargar, Flor Rezaei; Ajilchi, Bita; Ghoreishi, Monir Kalantar

Publicado por: Imprensa da Universidade de Coimbra

URL

persistente: URI:http://hdl.handle.net/10316.2/38628

DOI: $\quad$ DOI:http://dx.doi.org/10.14195/978-989-26-0775-7_24

Accessed : $\quad$ 26-Apr-2023 10:57:10

A navegação consulta e descarregamento dos títulos inseridos nas Bibliotecas Digitais UC Digitalis, UC Pombalina e UC Impactum, pressupõem a aceitação plena e sem reservas dos Termos e Condições de Uso destas Bibliotecas Digitais, disponíveis em https://digitalis.uc.pt/pt-pt/termos.

Conforme exposto nos referidos Termos e Condições de Uso, o descarregamento de títulos de acesso restrito requer uma licença válida de autorização devendo o utilizador aceder ao(s) documento(s) a partir de um endereço de IP da instituição detentora da supramencionada licença.

Ao utilizador é apenas permitido o descarregamento para uso pessoal, pelo que o emprego do(s) título(s) descarregado(s) para outro fim, designadamente comercial, carece de autorização do respetivo autor ou editor da obra.

Na medida em que todas as obras da UC Digitalis se encontram protegidas pelo Código do Direito de Autor e Direitos Conexos e demais legislação aplicável, toda a cópia, parcial ou total, deste documento, nos casos em que é legalmente admitida, deverá conter ou fazer-se acompanhar por este aviso.

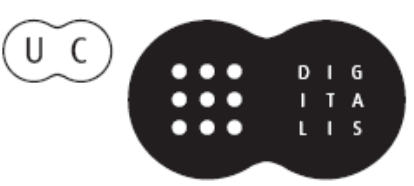




\section{INTERNATIONAL \\ STUDIES IN TIME \\ PERSPECTIVE}

MARIA PAULA PAIXÃO

JOSÉ TOMÁS DA SILVA

(COORD.)

VICTOR ORTUÑO

PEDRO CORDEIRO

(EDITORS)

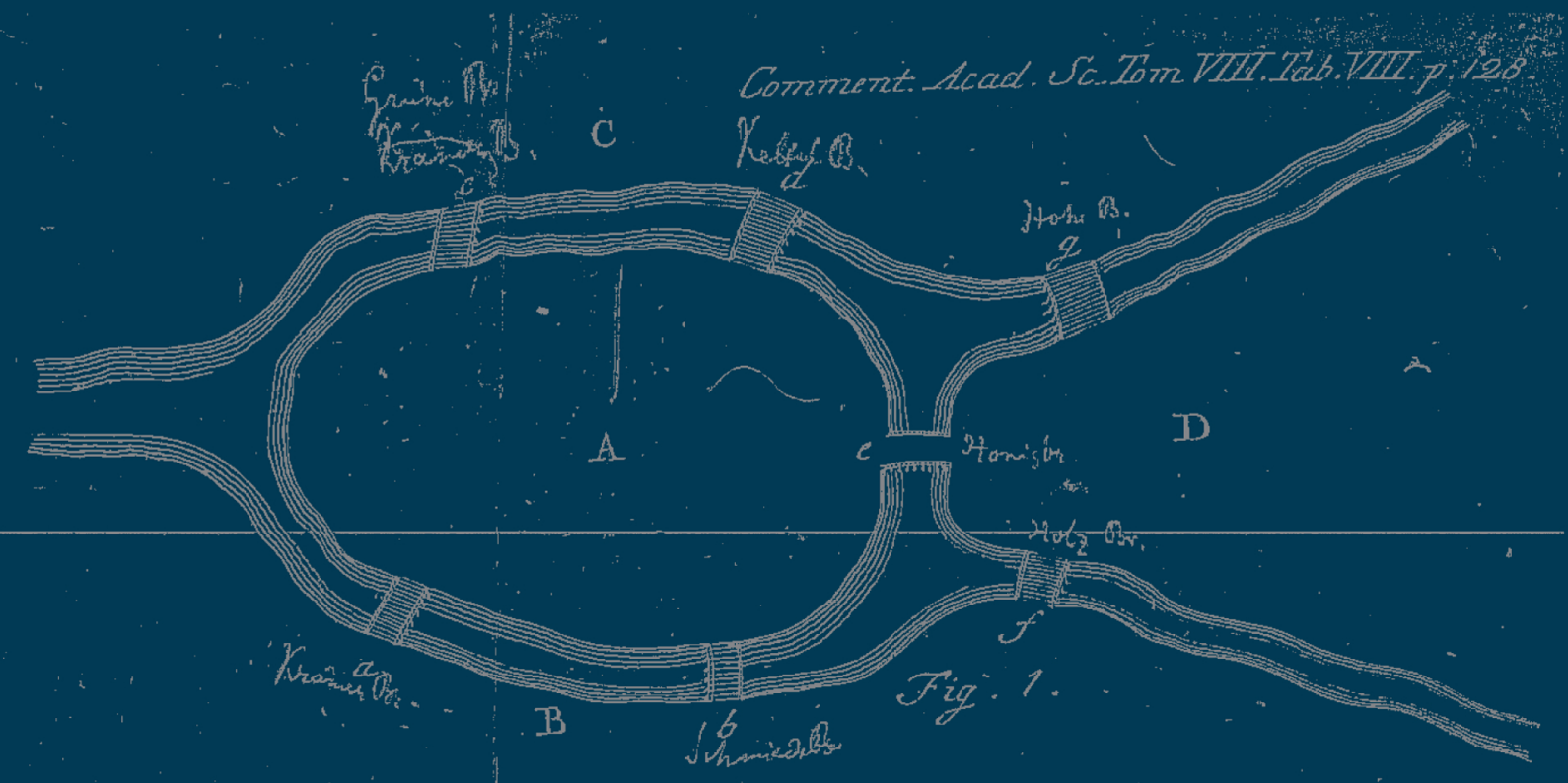

IMPRENSA DA

UNIVERSIDADE

DE COIMBRA

COIMBRA

UNIVERSITY

PRESS 


\section{Chapter 24 \\ EFFECT OF TEACHING CREATIVE AND CRITICAL THINKING SKILLS ON DEFENSE STYLES AND MENTAL HEALTH IN ADOLESCENTS}

\section{Flor Rezaei Kargar \\ Bita Ajilchi \\ Monir Kalantar Ghoreishi}

Department of Psychology, Faculty of Human Science, Islamic Azad University, Iran flor.rezaei@gmail.com

Aвstract: Adolescence is an essential period in life course which in mental health is at risk. On the other hand, defense mechanisms that are indicators of mental health have important role in this issue. It seems that promotion of thought can impress these variables. In this regard, the purpose of this study was to examine the effect of teaching creative and critical thinking skills on defense styles and mental health in adolescents attending high school. In an experimental study 40 students who were selected using random multilayer sampling, were divided into two test and control groups and responded to DSQ-40 and GHQ in group form. Then, the test group received 10 educational sessions (20 hours) focusing on thinking skills (creative and critical). The control group didn't receive any kind of intervention. Upon completion of educational sessions, both groups were retested with questionnaires of critical and creativity thinking, thinking. Independent t-tests showed significant increases in creativity and critical thinking in the experimental group. Furthermore, MANCOVA showed significant increases in mature defense style (and all of its mechanisms) and on general mental health. Additionally, a significant decrease were seen in somatic symptoms, anxiety and insomnia, and severe depression in experimental group.

Keywords: creative thinking, critical thinking, defense style, mental health.

\section{INTRODUCTION}

Today, modernity and technology cause many changes in life that can be strong sources of stress for people in general. This issue is very important for young people because adolescence is an essential period in life course in which mental health can be put to risk, especially in the absence of mature coping skills necessary to face adversity (Kessler, Berglund, Demler et al., 2005).

In order to cope with stress and maintain mental balance, defense mechanisms play an important role (Bond \& Perry, 2004). Indeed, defense mechanisms are unconscious processes (to avoid anxiety and protect the ego)are activated in threatening situations (Cooper, 1998; Freud, 1936 ) and that can also be seen as indicators of mental health (Feldman, Araujo, \& Steiner, 1996).

Andrews and colleagues (1989) classified defense mechanisms into three categories: mature (adaptive), neurotic, and immature defense styles (the two latter are maladap- 
tive). Researchers have confirmed the relations between maladaptive defense mechanisms and psychiatric symptoms (e.g. Sarno et al., 2010). Therefore, the promotion of adaptive defense styles and and the concomitant inhibition of maladaptive ones (Freud, 1894; cited in Zigler-Hill et al., 2008) is a key factor in improving mental health.

The findings of Ivans and Seeman (2000) support the theory that defense mechanisms development is based on the ego maturing levels. Since the ego is the location of cognition and intellect, the promotion of cognitive processes and thought functions can lead to ego development and consequently the use of adaptive defense mechanisms can increase mental health (Cramer, 2006; Chavez-Eakle, Lara, \& Cruz-Fuentes, 2006; Settersten \& Lauver, 2004).

It is clear that thinking skills are key components of cognition and thought. According to the classification of thinking skills made by Swartz and Parks (1994, cited in Burk \& Williams, 2008), creative and critical thinking are central cognitive capabilities. Creative thinking process involves the ability to produce original ideas, to perceive new and unsuspected relationships, or to establish a unique and improved order among seemingly unrelated factors (Piaw, 2010). Many scholars (Paul \& Elder, 2005; Giancarlo, Blohm \& Urdan, 2004; Silverman \& Smith, 2002; Glaser, 1985; cited in Piaw, 2010) have viewed critical thinking as the intellectually disciplined process of actively and skillfully conceptualizing, applying, analyzing, synthesizing, and evaluating information gathered from, or generated by, observation, experience, reflection, reasoning, or communication, as a guide to belief and action.

In this regard, in this study we want to examine the effect of teaching creative and critical thinking skills on defense styles and mental health of adolescents attending high school.

\section{METHOD}

\section{Participants}

Forty male students attending the $6^{\text {th }}$ degree (fifteen years old) in one high school in Tehran that was selected using random cluster sampling method were divided into two test and control groups by random assignment. Then, the participants responded to questionnaires defense styles and general mental health. Later, the test group received 10 educational sessions (20 hours, one session per week) focusing on the teaching of creative and critical thinking skills. Finally, both groups responded to a critical thinking skills test, a creativity inventory and the questionnaires used of pre-test.

\section{Instruments}

California Critical Thinking Skills Test form B (CCTST). It is a multiple-choice instrument that consists of six subscales including analysis, evaluation, inference, explanation, interpretation, and self-regulation. The internal reliability was computed (it oscillated between 0.78 and 0.84 ). Validity was measured by correlating the CCTST with the Scholastic Aptitude Test verbal scores (correlation of 0.55) (Facione, 2006).

Abedi-Scumacher creativity Test (O'Neil, Abedi and Spielberger, 1994). It is a multiple choice test comprising 60 questions in which students rate themselves on a three-point scale. It measures fluency, flexibility, originality, and elaboration. Azumendi, Villa and Abedi (1996; cited in Cropley, 2005) reported internal reliability of 0.61 to 0.75 for the four subscales. 
Questionnaire of defense style DSQ-40 (Andrews, Sing \& Bond, 1993). This scale has 40 items corresponding to twenty defense mechanisms (two items for per mechanism), categorized in 3 defense styles: mature defense style, neurotic defense style, and immature defense style.. Reported Cronbach alpha for the original scales are satisfatory (Andrews et al., 1993). Cronbach alpha's for the Persian version, used in the present study, obtained in a student sample were respectively $0.75,0.73$, and 0.74 . The test-retest coefficient after four weeks was 0.82 (Besharat et al. 2001).

The General Health Questionnaire, GHQ-28 (Goldberg, 1972). It consists of 28 items; the higher the score the lower the psychological well-being. It provides four sub-scales respectively tapping somatic symptoms, anxiety and insomnia, social dysfunction, and severe depression. Test-retest reliability has been reported to oscillate between 0.78 and 0.90 (Robinson \& Price, 1982; cited in Sterling, 2011); Cronbach's $\alpha$ oscillate between 0.90-0.95 (Failde and Ramos, 2000; cited in Sterling, 2011).

\section{Results}

Table 1 - Descriptive statistics of variables

\begin{tabular}{|c|c|c|c|c|c|}
\hline & & \multicolumn{2}{|c|}{ Experimental group } & \multicolumn{2}{|c|}{ Control group } \\
\hline & Group & Mean & SD & Mean & SD \\
\hline \multirow{2}{*}{ Mature defense style } & Pre test & 46.10 & 9.47 & 50.75 & 11.92 \\
\hline & Post test & 50.75 & 11.92 & 45.55 & 6.93 \\
\hline \multirow{2}{*}{ Neurotic defense style } & Pre test & 44.95 & 10.56 & 48.95 & 8.80 \\
\hline & Post test & 48.15 & 9.99 & 45.5 & 6.93 \\
\hline \multirow{2}{*}{ Immature defense style } & Pre test & 124.3 & 25.91 & 130.8 & 23.88 \\
\hline & Post test & 120.9 & 28.56 & 127.5 & 22.25 \\
\hline \multirow{2}{*}{ General health } & Pre test & 28.05 & 11.51 & 28.60 & 10.02 \\
\hline & Post test & 24.65 & 7.93 & 29.15 & 11.36 \\
\hline \multirow{2}{*}{ Somatic health } & Pre test & 5.20 & 3.38 & 5.60 & 3.56 \\
\hline & Post test & 4.45 & 3.68 & 6.35 & 3.91 \\
\hline \multirow{2}{*}{ Anxiety and insomnia } & Pre test & 4.90 & 4.28 & 5.40 & 3.26 \\
\hline & Post test & 1.70 & 2.23 & 5.10 & 4.48 \\
\hline \multirow{2}{*}{ Social dysfunction } & Pre test & 14.55 & 2.63 & 14.10 & 2.95 \\
\hline & Post test & 14.75 & 3.39 & 13.10 & 3.82 \\
\hline \multirow{2}{*}{ Severe depression } & Pre test & 3.25 & 5.49 & 3.65 & 4.67 \\
\hline & Post test & 2.05 & 2.89 & 4.65 & 7.07 \\
\hline
\end{tabular}


Table 1 showed that mature defense style increased but neurotic defense style, immature defense style, general health and its components decreased in experimental group.

Table 2 - Independent T-Test for creative and critical thinking between experimental and control groups

\begin{tabular}{|l|c|c|c|c|c|c|}
\hline \multirow{2}{*}{} & \multicolumn{2}{|c|}{ Experimental group } & \multicolumn{2}{c|}{ Control group } & \multicolumn{2}{|c|}{} \\
\cline { 2 - 7 } & Mean & SD & Mean & SD & $\mathrm{t}(38)$ & $\mathrm{P}<$ \\
\hline Creative thinking & 89.75 & 16.97 & 79.90 & 18.23 & 2.77 & .001 \\
\hline Critical thinking & 10.80 & 2.35 & 7.60 & 2.76 & 3.95 & .005 \\
\hline
\end{tabular}

Table 2 showed that creative and critical thinking significantly increased in experimental group after teaching.

Table 3 - Defense style differences before and after teaching

\begin{tabular}{|l|l|c|c|c|c|c|}
\hline Source & \multicolumn{1}{|c|}{ Dependent Variable } & Sum of Squares & $\begin{array}{c}\text { Mean } \\
\text { Square }\end{array}$ & $\mathrm{F}(1,35)$ & $\mathrm{P}<$ & $\begin{array}{c}\text { Effect } \\
\text { Size }\end{array}$ \\
\hline Group & Post test for Mature Defense style & 695.83 & 695.83 & 10.12 & .003 & .224 \\
\hline & Post test for Neurotic Defense style & 169.72 & 169.73 & 2.54 & .120 & .068 \\
\hline & Post test for Neurotic Defense style & 152.87 & 152.87 & 0.356 & .554 & .010 \\
\hline Error & Post test for Mature Defense style & 2406.67 & 68.76 & & & \\
\hline & Post test for Neurotic Defense style & 2341.75 & 66.91 & & & \\
\hline Total & Post test for Neurotic Defense style & 15012.18 & 428.92 & & & \\
\hline & Post test for Mature Defense style & 96618.00 & & & & \\
\hline & Post test for Neurotic Defense style & 90672.00 & & & & \\
\hline & Post test for Neurotic Defense style & 642366.00 & & & & \\
\hline
\end{tabular}

The results of the MANCOVA (see Table 3) show that the mature defense style increased in posttest in the experimental group (after the teaching sessions). Effect sizes of this variable are 0.224. Using Cohen's instructions (1988) suggesting that large effect sizes are higher than 0.14 , it can be concluded that the effect size observed in this study is in that range.

On the other hand the MANCOVA results obtained in the mental health indicators (see Table 4) point out that the scores of general health, somatic symptoms, anxiety and insomnia, and severe depression significantly decreased in posttest in the experimental group (after the teaching sessions). Effect sizes for these variables are respectively 0.124 , $0.109,0.248$ and 0.114 , expressing medium to large effect sizes. 
Table 4 - General health differences before and after the training program

\begin{tabular}{|l|l|c|c|c|c|c|}
\hline Source & Dependent Variable & Sum of Squares & $\begin{array}{c}\text { Mean } \\
\text { Square }\end{array}$ & F (1,33) & P < & $\begin{array}{c}\text { Effect } \\
\text { Size }\end{array}$ \\
\hline Group & Post test of general health & 166.912 & 166.912 & 4.669 & .038 & .124 \\
\hline & Post test of somatic symptoms & 33.017 & 33.017 & 4.046 & .050 & .109 \\
\hline & Post test of anxiety and insomnia & 98.633 & 98.633 & 10.864 & .002 & .248 \\
\hline & Post test of social dysfunction & 25.667 & 25.667 & 2.141 & .153 & .061 \\
\hline & Post test of severe depression & 74.056 & 74.056 & 4.226 & .048 & .114 \\
\hline & Post test of general health & 1179.721 & 35.749 & & & \\
\hline & Post test of somatic symptoms & 269.289 & 8.160 & & & \\
\hline & Post test of anxiety and insomnia & 299.611 & 9.079 & & & \\
\hline & Post test of social dysfunction & 395.535 & 11.986 & & & \\
\hline & Post test of severe depression & 578.293 & 17.524 & & & \\
\hline & Post test of general health & 32794.000 & & & & \\
\hline & Post test of somatic symptoms & 1750.000 & & & & \\
\hline & Post test of anxiety and insomnia & 1054.000 & & & & \\
\hline & Post test of social dysfunction & 8279.000 & & & & \\
\hline & Post test of severe depression & 1626.000 & & & & \\
\hline
\end{tabular}

\section{Discussion \& Conclusion}

This study indicated that creative and critical thinking skills as well and mature defense style increased after the teaching sessions. This finding is consonant with Ivans and Seeman (2000), and also Cramer (2006) studies, that argued that adaptive defense styles can be enhanced by improving the ego functions. While defense mechanisms are generally conceived as unconscious processes (Freud, 1996; Cramer, 2006), this study evidenced that they are subjected to change via the manipulation of conscious cognitive processes.

Furthermore, this study showed that teaching creative and critical thinking skills also promote mental health. This finding is in line with Krystal (1988), Parisooz (2011), Khandaghi and Pakmehr (2011) studies, which produce evidence that critical thinking skills and mental health indicators are mutually related.

Studies carried out respectively by Schwarzkopf (1981), Hermann (1987), Shubert (1988), Krystal (1988), Chavez-Eakle, Lara, \& Cruz-Fuentes (2006), Khosravani and Gilani (2007), Ourang, Azad Fallah and Dezhcam (2010) have reached similar conclusions.

Indeed, when someone uses creative and critical thinking skills, he/she is involved in healthy behaviors (Settersten \& Lauver, 2004), such as, adaptive decision making, and consequently diminishes the possibility of experiencing ill-being, such as despair, somatic symptoms, anxiety and depression. 
In conclusion, it can be said that teaching creative and critical thinking skills contributes to the reduction of problems and difficulties in the adolescents.

\section{REFERENCES}

Andrews, G., Pollock, C., Stewart, M. (1989). The determination of defense style by questionnaire. Arch Gen Psychiatry, 46, 455-60.

Andrews, G., Singh, M., \& Bond, M. (1993). The defense style questionnaire. Journal of Nerve and Mental Disorder, 19(1), 246-56.

Besharat, M. A., Sharifi, M., Iravani, M. A. (2001). The relationship between attachment and defense mechanisms. Journal of Psychology, 19, 277-289, (In Persian).

Bond, M., Grander, S., Christian, J., \& Sigal, J. J. (1983). Empirical study of self-rated defense style. Archive of General Psychiatry, 40, 333-338.

Bond, M. \& Perry, J. C. (2004). Long-term changes in defense style with psychodynamic psychotherapy for depressive, anxiety and personality disorders. American Journal of Psychiatry, $161,1665-1671$.

Burke, L. A. and Williams, J. M. (2008). Developing Young Thinkers: An intervention aimed to enhance children`s thinking skills. Thinking skills and Creativity, 3(2), 104-124.

Chavez-Eakle, R. A., Lara, M. C., \& Cruz-Fuentes, C. (2006). Personality: A possible bridge between creativity and psychopathology? Creativity Research Journal, 18(1), 27-38.

Cooper, S. H. (1998). Changing notions of defense within psychoanalytic theory. Journal of Personality, 66, 947-964.

Cramer, Ph. (2006). Protecting the self: Defense mechanisms in action. New York, NY: The Guilford Press.

Cropley, A. J. (1990). Creativity and mental health in everyday life. Creativity Research Journal, 3, $167-178$.

Cropley, A. J. (2005). Creativity in education \& Learning: a guide for teachers and educators. Oxon: Routledge Falmer

Cohen, J. W. (1988). Statistical power analysis for the behavioral sciences ( $2^{\text {nd }}$ ed.). Hillsdale, NJ: Lawrence Erlbaum Associates.

FaCione, P. A. (2006). Critical thinking: What it is and why it counts. Millbrae, CA: California Academic Press.

Feldman S. S., Araujo K. B., Steiner H. (1996) Defense mechanisms in adolescents as a function of age, sex and mental health status. J Am Acad Child Adolesc Psychiatry 35:1344-1354.

Freud, A. (1936). The ego and the mechanisms of defense. New York: International Universities Press.

Furnham, A. \& Nederstrom, M. (2010). Ability, demographic and personality predictors of creativity. Personality and Individual Differences, 48(8), 957-961.

Kessler, R. C., Berglund, P., Demler, O., et al. (2005). Lifetime prevalence and age-of-onset distributions of DSM-IV disorders in the National Comorbidity Survey replication. Archives of General Psychiatry, 62, 593-602.

Khandaghi, M. A. \& Pakmehr, H. (2010). The relationship between students' critical thinking and mental health in Mashad University of Medical Sciences. Journal of Fundamental of Mental Health, 13(2), 3-114.

Khosranani, S. \& Gilani, B. (2007). Creativity and mental health. Journal of Psychology and Education, 37(2), 65-73. 
Ourang, T., Azad Fallah, P., \& Dezhram, M. (2010). The Study of Defense Mechanisms Pattern Regarding Creative Thinking Level. Advances in Cognitive Science, 12(3), 49-58.

PIAw, C. Y. (2010). Building a test to assess creative and critical thinking simultaneously. Procedia Social and Behavioral Sciences, 2, 551-559.

PARIsozz, A. (2010). Effect of critical thinking teaching on mental health and academic achievement in female student of high school. Master`s Thesis of psychology. Tehran: Allameh Tabatabaei University.

Sarno, I., Madeddu, F., \& Gratz, K.L. (2010). Self-injury, psychiatric symptoms, and defense mechanisms: Findings in an Italian nonclinical sample. European Psychiatry, 25(3), 136-145.

Settersten, L., and Lauver, D.R. (2004). Critical Thinking, Perceived Health Status, and Participation in Health Behaviors. Nursing Research, 153(1),11-18.

Sterling, M. (2011). General Health Questionaire- 28 (GHQ-28). Journal of Physiotherapy, 57, 259.

Zeigler-Hill, V., Chadha, S., \& Osterman, L. (2008). Psychological defense and self-esteem instability: Is defense style associated with unstable self-esteem? Journal of Research in Personality, 42, 348-364. 